\title{
ON THE MALES OF WAGNERIANA RORAIMA LEVI AND \\ W. YACUMA LEVI (ARANEAE, ARANEIDAE)
}

\author{
Erica Helena Buckup ${ }^{1}$ \\ Ricardo Pinto-da-Rocha ${ }^{2}$
}

\begin{abstract}
The males of Wagneriana roraima Levi, 1991 and $W$. yacuma Levi, 1991 are described and illustrated for the first time.

KEY WORDS. Araneae, Araneidae, Wagneriana, taxonomy
\end{abstract}

The spider genus Wagneriana F.P.-Cambridge, 1904 was revised by LEVI (1991). Since that time, one species was described from South Brazil by PINTO-DAROCHA \& BUCKUP (1995). The present paper supplements these studies by describing, the first known males of $W$. roraima Levi, 1991 and $W$. yacuma Levi, 1991. The genus comprises 40 known species, 26 of wich based on both sexes, six on males and eight only on females.

The style of the descriptions and the abbreviations used in the text follows that of LEVI (1991) and PINTO-DA-RoCHA \& BUCKUP (1995). All measurements are in millimeters. Specimens examined are deposited in the following collections: (MCN) Museu de Ciências Naturais, Fundação Zoobotânica do Rio Grande do Sul, Porto Alegre; (MCP) Museu de Ciências da Pontifícia Universidade Católica do Rio Grande do Sul, Porto Alegre; (MZSP) Museu de Zoologia, Universidade de São Paulo, São Paulo.

\section{Wagneriana roraima Levi, 1991}

Figs 1,3

Wagneriana roraima Levi, 1991: 410, figs 187-190, female holotype and female paratype from Ilha de Maracá (rio Uraricoera), Roraima, Brazil (29.VII.1987, A.A. Lise leg.), MCN-19655 and MCN-18808, respectively (examined). - Platnick, 1993: 467.

Male description (MCN-21556). Total length 4.00. Carapace 2.30 long, 1.65 wide; abdomen 2.40 long, 1.60 wide. Carapace dark yellow anteriorly with a brown transverse band behind eyes, sides of thoracic region brown. Some white setae behind eyes. Sternum dark yellow brown. Legs yellow with brown rings, indistinct in legs III and IV. Fourth trochanter with one short macroseta. Eyes size and interdistances: AME 0.17; ALE 0.10; PMA 0.12; PLE 0.10; AME-AME 0.11; AME-ALE 0.22; PMA-PMA 0.13; PME-PLE 0.25. Abdomen with four pairs of

1) Museu de Ciências Naturais, Fundação Zoobotânica do Rio Grande do Sul. Caixa Postal 1188, 90001-970 Porto Alegre, Rio Grande do Sul, Brasil.

2) Museu de Zoologia, Universidade de São Paulo. Caixa Postal 7172, 01064-970 São Paulo, São Paulo, Brasil. 
lateral tubercles and two posterior median ones (Fig. 1). Venter of abdomen with a black square constricted posteriorly, with white pigment line on each side. Leg spination: femur I d5, v3, r4; patellae I-II d1, p2, r1; tibia I d4, v7, p5, r3; metatarsi I-II d2; femur II v4; tibia II d3, v9, p5, r1; femur III d2, p1; patellae III-IV d2, p1, r1; tibia III v3, p2, d1; metatarsus III d1; femur IV d3, v6, p1, r1; tibia IV d1, v5, p 1; metatarsus IV d3. Femora length: 2.55/2.07/1.22/1.95. Patellae: 0.87/0.77/0.52/0.67. Tibiae: 0.87/1.35/0.72/1.22. Metatarsi: 1.60/1.40/0.75/1.22. Tarsi: 0.60/0.55/0.42/0.47. Total: 7.49/6.14/3.63/5.53.

Variation. Total length of males 4.00 to $4.55(n=3)$.

Remarks. Males and females have been collected in the same locality and seem to be conspecific. LEVI (1991) recorded four species from Maracá Island: Wagneriana maseta Levi, 1991, W. jelskii (Taczanowski, 1873), W. acrosomoides (Mello-Leitão, 1939), all based on both sexes, and W. roraima was reported only by females up to now.

Diagnosis. The male palpus of Wagneriana roraima (Fig. 3) differs from that of W. silvae Levi, 1991 (see LEVI 1991: 407, fig. 186) by having a median apophysis smaller with a subapical keel, by the edge of tegulum evenly rounded, by the different shape of terminal apophysis and by the abdomen with 10 tubercles.

Material examined. BRAzIL, Roraima: Ilha de Maracá (rio Uraricoera), 1 male 04.XII.1987, E.H. Buckup leg. (MCN-21556); 1 male 05.XII.1987, A.A. Lise leg., (MCN-23941); 1 female 17.VII.1987, A.A. Lise leg., (MCN-24021); 1 male 31.I-14.II.1992, A.B. Bonaldo leg. (MCP-1870).

\section{Wagneriana yacuma Levi, 1991}

\section{Figs 2, 4}

Wagneriana yacuma Levi, 1991: 408, figs 172-175, female holotype, Espíritu, Río Yacuma, El Beni, Bolivia, 15.IV.1954, W. Forster \& O. Schindler leg., in Zoologische Staatssamlung, Munich (not examined). -Platnick, 1993: 467.

Male description (MZSP-14535). Total length 4.70. Carapace: 2.20 long, 1.55 wide; abdomen: 2.75 long, 1.60 wide. Cephalic area dark yellow with some brown pigment behind eyes on a transverse band; dark-brown on sides of thoracic region; carapace with white setae and a deep round pit on the thoracic region. Sternum dark-brown. Legs yellowish with black rings, I and II darker. Trochanter IV with two conspicuous macrosetae. Eyes size and interdistances: AME 0.17; ALE 0.07; PME 0.12; PLE 0.07; AME-AME 0.10; AME-ALE 0.20; PME-PME 0.10; PME-PLE 0.22. Abdomen with four pairs of lateral tubercles and three posterior median tubercles (Fig. 2). Venter with white pigment square enclosing some black pigment in the median longitudinal area. Leg spination: femur I d6, v2, p4, r1; patellae I-II d1, r1, p2; tibia I d3, v7, p3, r6; femur II d5, v6, p1; tibia II v12, d2, p5, r1; femur III d2; patellae III-IV d1, p1, r1; tibia III d1, v7, p1, r1; metatarsi III-IV d1; femur IV d4; tibia IV d3, p1, r1. Femora length: $2.25 / 1.75 / 1.20 / 1.65$. Patellae: 0.80/0.70/0.50/0.60. Tibiae: 1.55/1.15/0.75/1.00. Metatarsi: 1.15/1.05/0.65/0.95. Tarsi: 0.55/0.50/0.40/0.44. Total 6.30/5.15/3.50/4.64. 

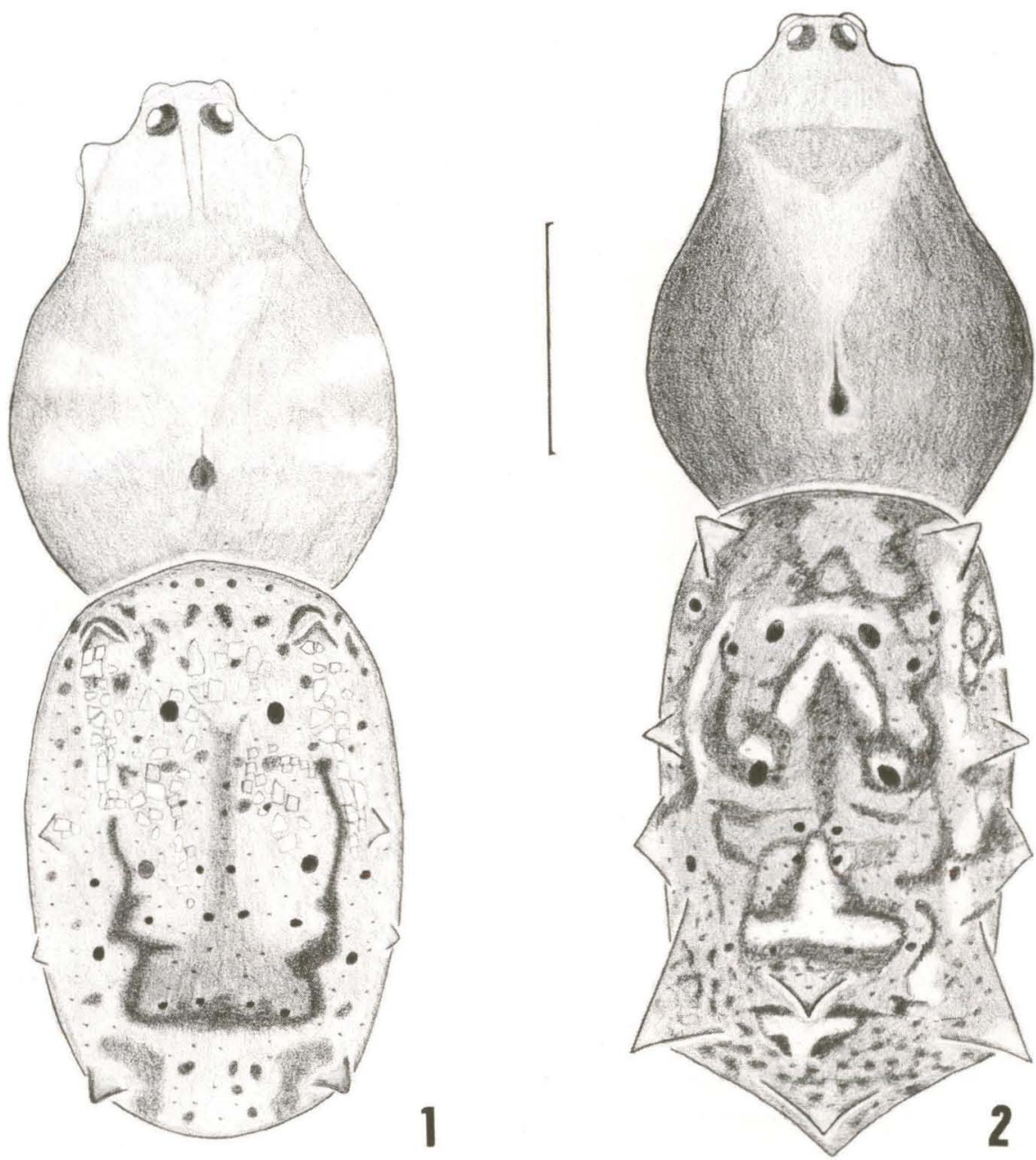

Figs 1-2. (1) Male of Wagneriana roraima (MCN-21556); (2) male of W. yacuma (MZSP-14535). Scale bar $=1.0 \mathrm{~mm}$.

Variation. Total length of males 4.25 to $5.15(n=5)$. One male has a postanal tail with a prominent second median posterior tubercle. Total length of females 4.70 to $6.00(\mathrm{n}=10)$. One female has a tail; two have a brown carapace; dorsum of the abdomen with a dark median band in three females or with more white pigment in two females.

Remarks. Males, females and immatures have been collected together in the same locality. The species is recorded for the first time from Brazil.

Diagnosis. The male palpus of Wagneriana yacuma (Fig. 4) has two lobes on the tegulum similar to that of W. taim Levi, 1991 (see LEVI 1991: 387, fig. 76) but the apical one is longer; distinguishes by the long embolus and conductor, the 
median apophysis distally bent and by the shape of terminal apophysis with a lobe and a thin weakly projection, difficult to see in more sclerotized palpus.

Distribution. Bolivia (El Beni); Brazil (Mato Grosso and Mato Grosso do Sul).

Material examined. BraziL, Mato Grosso: Poconé (Fazenda Santa Inês), 3 male, 9 female, 15 immatures 04-10.VIII.1992, A.A. Lise \& A. Braul Jr. leg. (MCP-2312); 1 male, 1 female same data (MZSP); 1 male same data (MCN-27096); Mato Grosso do Sul: Miranda, 1 female 06.V.1991, A.C. Meyer leg. (MCN-21005).
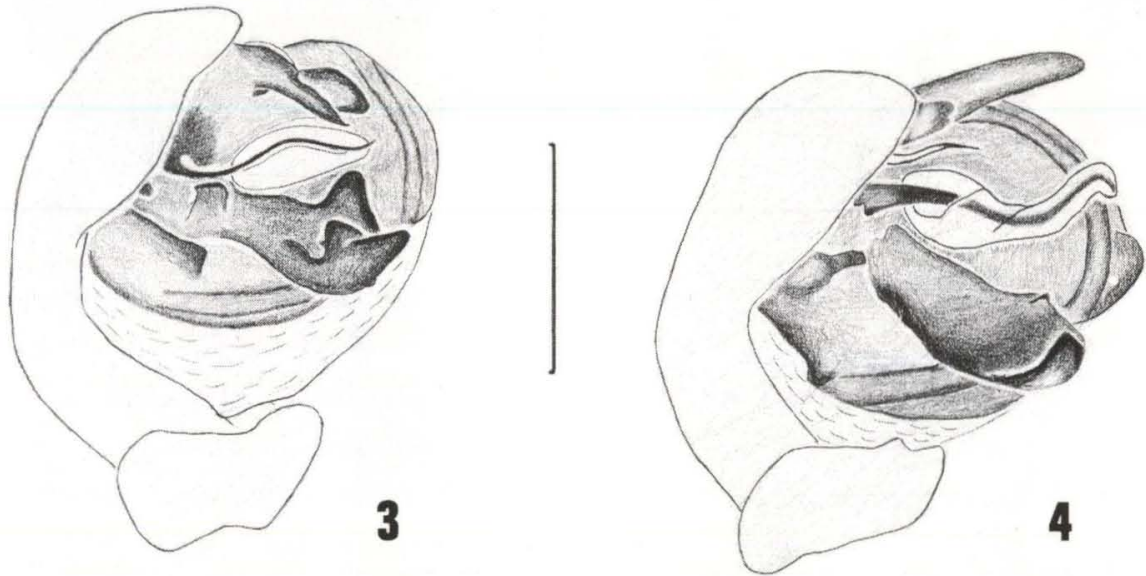

Figs 3-4. Mesal view of left palpus of Wagneriana spp.. (3) W. roraima; (4) W. yacuma. Scale bar $=0.5 \mathrm{~mm}$.

ACKNOWLEDGMENTS. We are indebted to Dr. Arno A. Lise, curator of the MCP collection, for loan and donation of specimens to MCN and MZSP.

\section{REFERENCES}

LEVI, H.W. 1991. The Neotropical orb-weaver genera Edricus and Wagneriana (Araneae: Araneidae). Bull. Mus. Comp. Zool., Cambridge, 152 (6): 363-415. PINTO-DA-RochA, R. \& E.H. BuCKUP. 1995. Wagneriana levii, a new species of Araneidae from Brazil (Araneae). Iheringia, Sér. Zool., Porto Alegre, 79: 159-161.

PlatNICK, N.I. 1993. Advances in Spider Taxonomy 1988-1991. New York, The New York Entomological Society, 864p. 